\title{
Production and vegetative growth of coffee trees under fertilization and shade levels
}

\author{
Catalina Jaramillo-Botero'; Ricardo Henrique Silva Santos ${ }^{1 *}$; Herminia Emilia Prieto \\ Martinez ${ }^{1}$; Paulo Roberto Cecon²; Merci Pereira Fardin ${ }^{1}$ \\ ${ }^{1} U F V$ - Depto. de Fitotecnia, Av. P.H. Rolfs, s/n-36570-000 - Viçosa, MG - Brasil. \\ ${ }^{2} U F V-$ Depto. de Estatística. \\ *Corresponding author <rsantos@ufv.br>
}

\begin{abstract}
It is difficult to separate the effects of light reduction versus nutrient and water competition in agroforestry systems. The objective of this experiment was to evaluate the effect of shading and fertilizer supply on the vegetative development and yield of Coffea arabica over six years. The coffee trees were covered with shade screens (photosynthetically active radiation reduction up to $48 \%$ ) and fertilized from 100 to $40 \%$ of the recommended amount from 2001 on. Leaf area, number of leaves, number of nodes, leaf area per branch and, yield were determined. Although no effect of fertilization was found, shading influenced the number of nodes, leaf area and production from the third year on. The number of nodes and yield decreased as shading increased. The effect of the yield bienniallity was more evident in the unshaded trees, which yielded an average of 2,646 kg ha ${ }^{-1}$. The trees under $48 \%$ shading yielded an average of 2,094 $\mathrm{kg} \mathrm{ha}^{-1}$. After 2004 the leaf area per branch increased as the shade increased, at the end of both the maximum and minimum growth periods. During the first three years, the coffee trees do not change their vegetative or productive characteristics as a response to shading. The shade effects become more intense after the beginning of the higher yield period. The shaded coffee trees have a larger leaf area and a smaller number of nodes than the coffee trees under full sun. The yield decreases as photosynthetically active radiation limitation increases, and yield bienniallity is less intense in shaded trees.
\end{abstract}

Key words: Coffea arabica, bienniallity, plant growth and development, yield

\section{Produção e crescimento vegetativo de cafeeiros sob fertilização e sombreamento}

\begin{abstract}
RESUMO: Em sistemas agroflorestais é difícil separar os efeitos da competição por luz daquela por água e nutrientes. O objetivo do experimento foi avaliar o efeito do sombreamento e do fornecimento de fertilizantes sobre o desenvolvimento vegetativo e a produtividade de cafeeiros arábica ao longo de seis anos. Os cafeeiros foram cobertos com telas sombreadoras (redução da radiação fotosinteticamente ativa em até $48 \%$ ) e fertilizados de 100 até $40 \%$ da recomendação. Foram determinados a área da folha, o número de folhas, o número de nós, a área foliar por ramo e a produtividade dos cafeeiros. Embora não houvesse efeito da fertilização, o sombreamento influenciou o número de nós, a área da folha e a produção a partir do terceiro ano. O número de nós e a produtividade reduziram conforme aumentou o sombreamento. Cafeeiros sob pleno sol apresentaram maior bienalidade da produção e produtividade média de $2646 \mathrm{~kg} \mathrm{ha}^{-1}$. Cafeeiros sob $48 \%$ de sombreamento produziram em média $2094 \mathrm{~kg} \mathrm{ha}^{-1}$. Após três anos a área foliar aumentou com o aumento do sombreamento, tanto no final do período de maior quanto de menor crescimento. Nos três primeiros anos, os cafeeiros não diferiram nas características vegetativas ou reprodutivas devido ao sombreamento. Os efeitos do sombreamento tornam-se mais intensos após o início do período de altas produtividades. Cafeeiros sombreados apresentam folhas maiores e menor número de nós do que cafeeiros sob pleno sol. Nos anos de alta produtividade esta decresce com o aumento do sombreamento e a bienalidade é menos intensa nos cafeeiros sombreados.

Palavras-chave: Coffea arabica, bienalidade, crescimento e desenvolvimento, produtividade
\end{abstract}

\section{Introduction}

Coffee (Coffea Arabica L.) production in agroforestry systems can offer many advantages to farmers interested in environmental services such as increasing local biodiversity, erosion reduction (Donald, 2004), improvement of water storage in soils (Lin and Richards, 2007), and mitigation of climatic extremes (Lin, 2007; Morais et al., 2006). It can also result in eco- nomic advantage by the generation of extra products and by the opportunity to explore alternative markets (Donald, 2004) and reduce the biennial pattern of coffee yield (Da Matta, 2004). Nevertheless, despite those potential benefits, the complex interactions between the abiotic components and species in agroforestry systems result in extremely variable coffee tree performance. In Costa Rica, under high rainfall and high soil organic matter, coffee trees intercropped with 
Eucaliptus deglupta trees showed similar (Schaller et al., 2003) or higher (van Kanten et al., 2004) production than coffee trees intercropped with Terminalia ivorensis or Erythrina poeppigiana.

Most coffee farmers in Brazil choose full-sun production. One of the reasons for this choice is the growth and yield reduction observed in shaded coffee trees compared with coffee trees under full sun (Campanha et al., 2004; Morais et al., 2006). In particular, under conditions of restricted water and nutrient availability the negative effect of low radiation on production becomes more evident (Da Matta, 2004). In agroforestry systems it is difficult to separate the effects of light reduction versus nutrient and water competition. A better understanding of the particular effects of light and nutrient restriction on coffee growth and yield will contribute to the design of coffee agroforestry systems more suitable to the Brazilian coffee farmer expectations. The objective of this study was to evaluate the effects of the limitation of photosynthetically active radiation and fertilizer supply on the vegetative development and production of coffee trees over six years.

\section{Material and Methods}

The work was carried out in Viçosa, state of Minas

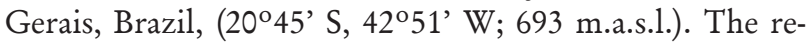
gion has cold dry winters and hot rainy summers, with an average temperature of $19.4^{\circ} \mathrm{C}$ (maximum $26.4^{\circ} \mathrm{C}$ and minimum $14.8^{\circ} \mathrm{C}$ ); average precipitation of $1,221 \mathrm{~mm}$ per year; and average global solar radiation of $1,416 \mathrm{~kJ} \mathrm{~m}^{-2}$ per day. The soil is classified as Xanthic Ferrasol, with $40 \%$ slope and northeastern exposure. Before the beginning of the experiment (September 2001) the soil characteristics were $\mathrm{pH}\left(\mathrm{H}_{2} \mathrm{O}\right) 5.1 ; 38.4 \mathrm{mmol}_{\mathrm{c}} \mathrm{dm}^{-3}$ exchangeable base cations, and $39.4 \mathrm{mmol} \mathrm{dm}^{-3}{ }^{\mathrm{c}}$ effective cation exchange capacity $(\mathrm{t}) ; 36.4$ and $134 \mathrm{mg} \mathrm{dm}^{-3}$ of $\mathrm{P}$ and $\mathrm{K}$, respectively, and 2.5 and $10.0 \mathrm{mmol} \mathrm{dm}^{-3}$ of $\mathrm{Ca}^{+2}$ and $\mathrm{Mg}^{+2}$. The $\mathrm{Al}$ content was $1.0 \mathrm{mmol} \mathrm{dm} \mathrm{dm}^{-3}$, and $\mathrm{H}^{+}+\mathrm{Al}^{+3}$ was $43.0 \mathrm{mmol}_{\mathrm{c}} \mathrm{dm}^{-3}$.

The coffee trees, cultivar 'Catuaí Vermelho CH 20772-5-99', were planted in 1989 and received a drastic pruning ( $0.3 \mathrm{~m}$ aboveground) in 1999 . The spacing was $1 \mathrm{~m}$ between trees and $3 \mathrm{~m}$ between rows. The coffee trees underwent four shade levels $(0 \%, 16 \%, 32 \%$ and $48 \%$ blockage of Photosynthetically Active Radiation), and four levels of fertilization $(100 \%, 80 \%, 60 \%$ and $40 \%$ of the recommended amount for the crop in full sun). The $4 \times 4$ factorial design was set up in randomized blocks with 3 replications.

Each plot, formed by 12 trees (ten border trees and two measured ones in the inner part of the plot), was covered and encircled with shade screens, which gave photosynthetically active radiation blockage of the previously mentioned levels. The shade screens were placed in December, 2001. Plots were distributed in the experimental area according to the position of the sun during the day, preventing shade interference among them. In the state of Minas Gerais, Brazil, the recommendations of fertilizers is based on actual yield estimate for each year. The yield estimate is made early in the season, when berries are at the pinhead stage. Yield estimates below $1200 \mathrm{~kg} \mathrm{ha}^{-1}$ are considered very low. The 100\% fertilization and liming doses applied were calculated based on the yield estimates of the coffee trees under full sun and receiving $100 \%$ fertilization (Table 1) and on the soil analysis of these plots.

The fertilizer was applied every year, divided into three applications in the months of November, December and January. The control of weeds was carried out three times a year in the summer rainy season, between November and March. When necessary, rust (Hemileia vastatrix) incidence and coccid infestation (Coccinelidae) were controlled in February with copper oxychloride or mineral oil respectively.

Actual levels of shade were determined by calculating the blocked photosynthetically active radiation percentage from the shade screen, measured with a bar ceptometer (Sunfleck ceptometer type CEP ${ }^{\circledR}$, Delta-T Devices Ltd, England) above the canopy of the coffee trees, at the beginning of the experiment. The average value of photosynthetically active radiation at noon on sunny days was: $1050 \mu \mathrm{mol} \mathrm{m} \mathrm{m}^{-2} \mathrm{~s}^{-1}$ on full sun exposure trees and, 882, 714 and $546 \mu \mathrm{mol} \mathrm{m}^{-2} \mathrm{~s}^{-1}$ for 16,32 and $48 \%$ of shade respectively.

The first evaluation of the vegetative characteristics of the trees was carried out in October, 2001, before the application of the treatments. The vegetative development of the coffee trees was evaluated in four plagiotropic branches per tree. The branches were situated on the

Table 1 - Yield estimates of coffee trees under full sun and 100\% of fertilizer and lime doses, and applied amounts of N, $\mathrm{P}_{2} \mathrm{O}_{5}, \mathrm{~K}_{2} \mathrm{O}$ and limestone from 2001 to 2007.

\begin{tabular}{|c|c|c|c|c|c|}
\hline Year & Yield estimates & $\mathrm{N}$ & $\mathrm{P}_{2} \mathrm{O}_{5}$ & $\mathrm{~K}_{2} \mathrm{O}$ & Limestone \\
\hline & $\mathrm{kg} \mathrm{ha}^{-1}$ & (- & $\mathrm{kg} \mathrm{ha}^{-}$ & - & $\mathrm{Mg} \mathrm{ha}^{-1}$ \\
\hline $2001-2002$ & $<800$ & 100 & 0 & 100 & 0.25 \\
\hline $2002-2003$ & 1,458 & 250 & 20 & 190 & 0.57 \\
\hline $2003-2004$ & 2,082 & 300 & 25 & 300 & 0.57 \\
\hline $2004-2005$ & 3,960 & 340 & 20 & 450 & 0.65 \\
\hline $2005-2006$ & $<1,200$ & 200 & 20 & 150 & 0.67 \\
\hline $2006-2007$ & 3,720 & 340 & 20 & 450 & 0.65 \\
\hline
\end{tabular}

Sci. Agric. (Piracicaba, Braz.), v.67, n.6, p.639-645, November/December 2010 
middle third of the trees, oriented to the north, south, east and west directions. On these branches we counted the number of nodes, the number of leaves $(>8 \mathrm{~cm})$ and the length and width of each leaf $(>8 \mathrm{~cm})$. The area of each leaf was calculated from the area of the rectangle determined by the leaf dimensions, adjusted by the equation $\mathrm{Y}=0.667 \mathrm{X}$, where $\mathrm{Y}=$ estimated leaf area $\left(\mathrm{cm}^{2}\right)$ and $\mathrm{X}=$ Area of its circumscribed rectangle $\left(\mathrm{cm}^{2}\right)$, according to the method of Tavares-Júnior et al. (2002). The leaf area of the branch was determined multiplying the average leaf area by the number of leaves per branch.

By 2003 the branches that had been chosen at the beginning of the experiment were located on the lower third of the tree. In September of this year we therefore began evaluating branches located on the middle third of the tree instead. Thus, the number of nodes and the leaf area per branch were divided into two periods, the first one from 2001 to 2003 and the second one from 2004 to 2006. The number of nodes in the first period is symbolized by NN1 and in the second period by NN2; the leaf area of the branch is likewise symbolized by BLA1 and BLA2.

All the vegetative development records were taken at the end of the greatest (March) and smallest (September) growth periods of the coffee trees in the Viçosa region (Silva et al., 2004). The growth of the coffee trees was evaluated by the number of nodes recorded at the end of the greatest growth period (March).

The bienniallity index measures the degree of variation in yields due to the physiological trade-off between vegetative and reproductive growth characteristics of coffee crop. The bienniallity yield index was calculated with the equation proposed by Lunz (2006) with modifications:

$$
\left\{\left[\frac{\operatorname{prod} 2-\operatorname{prod} 1}{\operatorname{prod} 1}\right]^{1 / 2}+\left[\frac{\operatorname{prod} 3-\operatorname{prod} 2}{\operatorname{prod} 2}\right]^{1 / 2}+\ldots\left[\frac{\operatorname{prod} n-\operatorname{prod} n-1}{\operatorname{prod} n}\right]^{1 / 2}\right\} / n
$$

prod $\mathrm{X}=$ production in the year $\mathrm{X}$, and $\mathrm{n}=$ number of years.

During the harvest, all the berries of the trees were collected, and their fresh mass was determined. Samples were taken and dried in the open air until reaching 12$13 \%$ moisture (dry berry), and after that the berries were counted and weighed in order to determine the mass of one berry $(\mathrm{g})$. The conversion factor of fresh berry to dry berry (0.36) was calculated and the value converted into hulled coffee using the formula $1 \mathrm{~g}$ dried berry = $0.5 \mathrm{~g}$ hulled coffee.

The yield data and the number of nodes were analyzed by analysis of variance $(p<0.05)$, according to a split-plot design, with the effect of the time in years (T) as the sub-plot. Branch leaf area was analyzed by analysis of variance $(p<0.05)$, according to a split-plot design, but with the sub-plot being the time in months (t). The data were subjected to a regression analysis of $p<0.05$. The curve fit numbers were used to adjust the equations. The models were chosen based on the signifi- cance of the regression coefficients, on the determination coefficient and on the phenomenon under study. The statistical analyses were performed using the software SAEG 9.1.

\section{Results}

The fertilizer levels did not influence any of the evaluated variables. The six year average production of coffee trees under $100 \%, 80 \%, 60 \%$ and $40 \%$ of fertilization was $1,481.51,1,436.98,1,330.13$ and $1,435.78 \mathrm{~g}$ per plant, respectively, and the differences were not significant $(p \geq 0.05)$. The number of nodes per branch during the first period was influenced by year. In the second period, the number of nodes per branch was influenced by year, shade, and the interaction between year and shade (Table 2).

The number of nodes per branch increased quickly during the first period (2001-2003), between one and three years after the drastic pruning. In the second period of evaluation (2004-2006), a greater increase in the number of nodes per branch in the unshaded trees was observed (Figure 1). The increase of the number of nodes from 2001 to 2003 varied from 197 - 287\% for the $48 \%$ and $0 \%$ shade levels respectively. Between 2004 and 2006 the increase was $83.7 \%$ for the trees under $48 \%$ shade and $149 \%$ for the unshaded trees (Figure 1). The regression equations are in Table 2.

There was no effect of either shade level or application of fertilizer on the leaf area per branch in the first period. No regression model accounted for this variable. The leaf area per branch in the second period (BLA2) was influenced by month and by shade level (Table 2). Over the years the leaf area per branch presented the well known cycle of decrease during the cold dry season and increase during the hot rainy season. In the first period of growth, this variation was more intense than in the second period. Between 2004 and 2006, shading influenced the leaf area per branch (Figure 2). The regression equations for these variables are

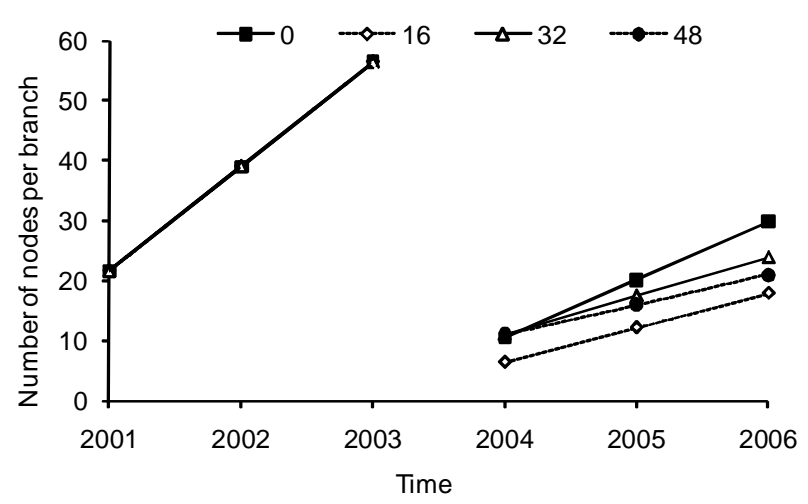

Figure 1 - Number of nodes per branch in coffee trees over time (years) for each shade level $(0,16,32$ or $48 \%$ of photosynthetically active radiation blockage). Average value in the first period (2001-2003) and time fit curves in the second period (2004-2006). 
Table 2 - Regression equations for the number of nodes in the first (NN1) and second period (NN2), time adjusted in years $(\mathrm{T})$, and leaf area per branch in the second period (BLA2), time adjusted in months $(\mathrm{t})$ and Production (g per plant) as a function of shade (\%photosynthetically active radiation blockage).

\begin{tabular}{lccc}
\hline Variable & & \multicolumn{1}{c}{ Adjusted Equation } & $\mathrm{R}^{2} / \mathrm{r}^{2}$ \\
\hline NN1 & & $\hat{\mathrm{Y}}=4.163+17.411 * \mathrm{~T}$ & 0.95 \\
\hline NN2 & & \\
& Shade $(\%)$ & & \\
& 0 & $\hat{\mathrm{Y}}=0.843+9.651 * \mathrm{~T}$ & 0.84 \\
& 16 & $\hat{\mathrm{Y}}=0.596+5.752 * \mathrm{~T}$ & 0.86 \\
& 32 & $\hat{\mathrm{Y}}=4.728+6.384 * \mathrm{~T}$ & 0.85 \\
\hline BLA2 & 48 & $\hat{\mathrm{Y}}=6.111+4.946 * \mathrm{~T}$ & 0.90 \\
\hline & & \\
& Shade (\%) & & \\
& 0 & $\hat{\mathrm{Y}}=379.03+205.29 * \mathrm{t}-34.30 * \mathrm{t}^{2}+1.32 * \mathrm{t}^{3}$ & 0.53 \\
& 16 & $\hat{\mathrm{Y}}=319.51+154.67 * \mathrm{t}-27.72 * \mathrm{t}^{2}+1.09 * \mathrm{t}^{3}$ & 0.47 \\
\hline Production & 32 & $\hat{\mathrm{Y}}=262.86+114.82 * \mathrm{t}-20.47 * \mathrm{t}^{2}+0.82 * \mathrm{t}^{3}$ & 0.67 \\
2005 & 48 & $\hat{\mathrm{Y}}=189.54+136.11 * \mathrm{t}-23.22 * \mathrm{t}^{2}+0.89 * \mathrm{t}^{3}$ & 0.73 \\
\hline 2006 & & $\hat{\mathrm{Y}}=3479.2-27.9 * \mathrm{~S}$ & 0.78 \\
2007 & & $\hat{\mathrm{Y}}=11.3+9.1 * \mathrm{~S}$ & 0.64 \\
\hline$* p<0.05$ & & $\hat{\mathrm{Y}}=3550.2-22.5 * \mathrm{~S}$ & 0.75 \\
\hline
\end{tabular}

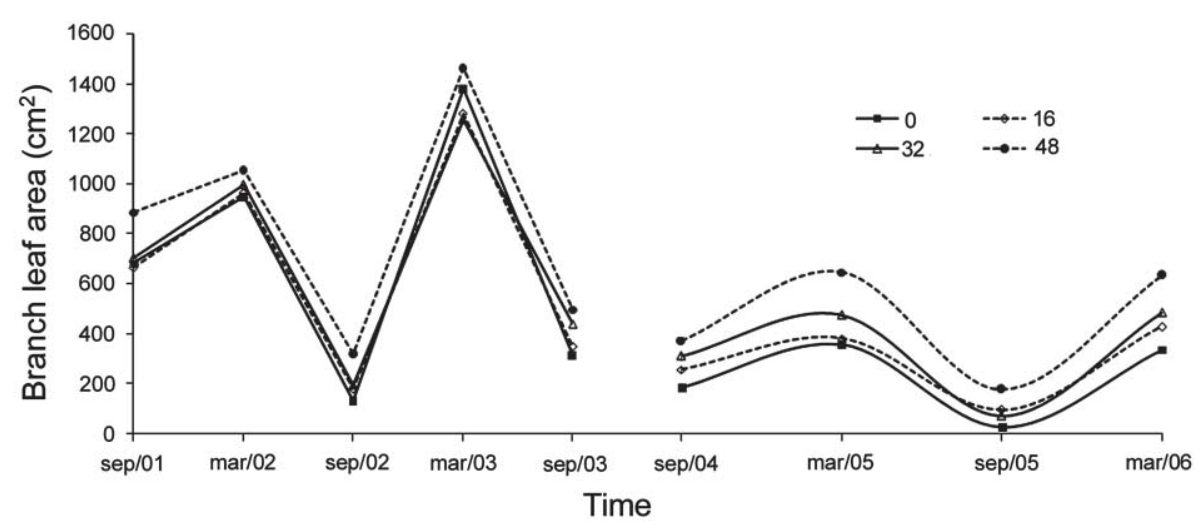

Figure 2 - Branch leaf area in coffee trees over time for each shade level $(0,16,32$ or $48 \%$ of photosynthetically active radiation blockage). Observed values in the first period (2001-2003) and time adjusted curves in the second period (2004-2006).

in Table 2. The effect of year, shade level, and the year $x$ shade level interaction influenced the production per tree. The yield had biennial behavior with greater oscillation of the values in the unshaded trees from 2004 onward (Figure 3).

The analysis within each year did not show any effect of shading on the production per tree during the first four years of the experiment (2001-2004). In these years the production was $442,1,422$ and 628 g per plant. In the years of high yields (2005 and 2007), the production of coffee trees decreased as the shade level increased (Table 2). In 2006 the increase in shading slightly increased the production (Table 2). The bienniality index was 13.49 for the trees under full sun and $4.12,3.73$, and 1.32 for the trees under 16,32 and $48 \%$ of shade, respectively.

\section{Discussion}

The absence of an effect of fertilization rate on the vegetative growth and development and the yield is difficult to explain. This result can be due in part to the great variability of response observed in the coffee trees under field conditions. There are reports of no effect from fertilization of coffee trees associated with Inga edulis in Colombia (Farfan and Mestre, 2004) and in Bra- 


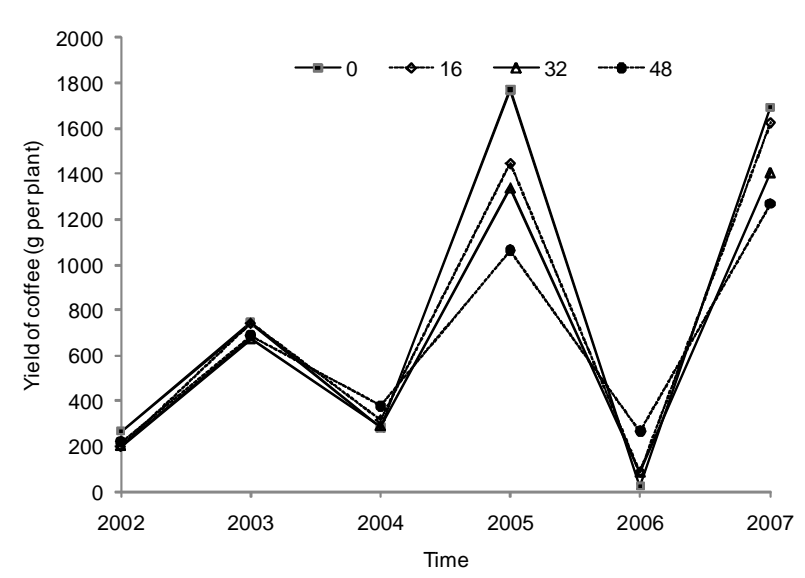

Figure 3 - Average values of yield per coffee tree in each shade level $(0,16,32$ or $48 \%$ of photosynthetically active radiation blockage) from 2002 to 2007.

zil (Espírito Santo state) in coffee trees under high tree density (Prezotti and Rocha, 2004). In an experiment evaluating four coffee cultivars fertirrigated for three years, there was a significant effect of fertilizer rate $(p<0.1)$ (Neves et al., 2006). Coffee is a perennial woody crop and, persisting many years in the field, it accumulates uncontrolled or previous effects from the environment. Another possible cause of the lack of fertilization effect in the experiment could be the presence of nutritional reserves in the soil of the shaded trees, which had a smaller load of berries. In these trees, the fertilizer supplied was not used completely due to the smaller nutrient demand, leaving residual nutrients for the following cycle. This detail was not considered in the subsequent fertilizations, and the applied amounts of fertilizer may have exceeded the amount of nutrients that were intended to be available for the tree. In future experiments a greater number of coffee trees per plot and/ or a greater number of replicates should be used, unless the field area required would introduce more variation instead of making the experiment more precise.

The lack of a shade effect on the number of nodes and on production between 2002 and 2004 indicates the existence of a period when shading does not influence coffee tree growth. Coffee tree requirements for light and nutrients increase sharply after the beginning of the higher yield stage (Da Matta, 2004), usually from the third harvest on. In addition, the leaves are sensitive organs to changes in the incident radiation (Cannell, 1985). Thus quick adaptation of leaves to conditions of low luminosity could help the trees to maintain growth levels similar to the trees under full sun. In the same period there was a fast increase in the number of nodes and of leaf area per branch. This increase was higher than the increase in the second evaluation period (2004-2007), suggesting that the coffee trees in the initial growth and yield stage had greater allocation of photosynthate for the formation of vegetative organs. In the second evaluation period the trees exhibited a great load of berries that caused growth and vegetative development reduction.
From 2004 onward the shaded trees presented a lower rate of increase in the number of nodes and a greater branch leaf area than coffee trees under full sun. There are reports of greater growth in height of coffee trees shaded with Cajanus cajan than full-sun grown coffee trees in the state of Paraná, Brazil, (Morais et al., 2003). Longer branches, wider diameter of the stem and a greater number of branches per tree have been observed in shaded trees in Cuba (Rodríguez et al., 2001). However, the unshaded trees usually have a greater accumulation of dry mass, since the high load of berries stimulates photosynthesis and the formation of new nodes (Cannell, 1985; Da Matta, 2004) and thicker leaves (Jaramillo-Botero et al., 2009), while the shading of coffee trees increases the effects of self-shading in reducing flower bud differentiation in inner parts of the tree $(\mathrm{Da}$ Matta, 2004).

In the experiment, the cycles of leaf fall and leaf formation in the coffee trees were clearly observed throughout the years. The branches presented smaller leaf area at the end of the cold and dry season and larger leaf area in the end of the hot and rainy season. In the study region, the coffee trees present higher growth rates until March, followed by a growth restriction stage from May to September, mainly caused by the low temperatures and the dry climate (Silva et al., 2004).

The presence of branches with higher leaf area during the cold and dry season at higher shade levels is a consequence of the greater leaf retention in these trees, as reported by Campanha et al. (2004). This can be due to the lower rate of soil moisture loss during the dry season as a consequence of the shading. In coffee trees under conditions of agroforestry systems a smaller transpiration rate per leaf unit than in unshaded trees has been reported (van Kanten and Vaast, 2006). Nevertheless, the same authors report a greater evapotranspiration in the agroforestry system due to the presence of trees. Neves et al. (2007) reported lower soil moisture in a coffee agroforestry system than in a full sun coffee crop. In the present experiment the artificial shading without the effect of tree competition prevented this effect from happening.

There was a reduction of the biennial pattern in the production of the coffee trees as shading increased, evidenced by the reduction of the bienniality index in the shaded trees. In the conditions of the experiment, it is possible that the low availability of photosynthetically active radiation for the shaded trees limited the stimulation necessary for the differentiation of the floral bud (Da Matta, 2004), reducing the number of berries (Jaramillo-Botero et al., 2009). Based on the physiology of the coffee tree after high production of berries, shaded coffee trees have smaller bienniality in their production (Da Matta, 2004). The overproduction of berries, caused by stimulation of many floral gems in the trees subjected to high solar radiation, leads to the exhaustion of the tree reserves and hampers growth in that year and production in the following year. In this way, the low produc- 
tion that follows a year of high production allows the recovery of nutrients and necessary growth, in order to bear a high berry load in the next productive cycle, causing a biennial pattern. Thus shaded trees present fewer and bigger berries and fewer dead branches than coffee trees under full sun (Jaramillo-Botero et al., 2009). Although Morais et al. (2009) reported that 50\% shading of coffee plants from April to October did not affect flower bud development or yield, the shading was imposed during the months of little growth and after the period of differentiation of the branch buds into flowers, while in the present work coffee plants were shaded all year round over a period of six years. Nevertheless, a lower bienniality does not mean higher yield.

The effect of shading on coffee productivity was significant after the beginning of the high yield stage. The increase in shading reduced the yield linearly in the years of higher yields, but had a weaker and opposite effect in the intervening years. The higher the berry load, the higher the drain of photoassimilates and the higher the photosynthetically active radiation requirements. Thus limitation of photosynthetically active radiation in years of high production reduces yield. The productivity response of the coffee trees to shading in agroforestry systems varies greatly depending on soil conditions and climate, but also depending on the yield level of the site or experiment (Jaramillo-Botero et al., 2006). Although the variation in production of shaded coffee is more influenced by factors like management practices or the intensity of inputs applied than by the available radiation for the trees (Romero-Alvarado et al., 2002), one must consider the yield level of the studied sites. A report of no effect of shading by Inga on coffee yield cited productivity of $725 \mathrm{~kg} \mathrm{ha}^{-1}$ (Peeters et al., 2003). In an on-farm study in the state of Chiapas, Mexico, the yields of high-shaded coffee $(60-80 \%)$ and medium-shaded coffee $(30-50 \%)$ were similar, around $1600 \mathrm{~kg} \mathrm{ha}^{-1}$, although data were taken for just one year (Lin, 2009). Furthermore, in agroforestry systems the discussion of effect of shading is confounded by the effect of competition for water and nutrients, which usually receive little or no attention. In the present experiment coffee trees were sampled over a period of six years and reached a very high yield, and the lower availability of photosynthetically active radiation in the shaded plants clearly limited the coffee yield.

\section{Conclusions}

Vegetative or productive characteristics of coffee trees did not change as a response to shading during an initial period of three years after the drastic pruning. The shade effects became more intense after the beginning of the high-yield stage of the coffee trees. Shaded coffee trees had a larger leaf area at the end of the maximum and minimum growth stages of the year and a smaller number of nodes than the coffee trees under full sun. The bienniallity of the production was less intense in the shaded trees, but in the years of high yields the increase of photosynthetically active radiation limitation decreases coffee yield.

\section{Acknowledgements}

The CNPq granted a PhD PEC-PG scholarship and supported the research project through the 478160/20046 grant.

\section{References}

Campanha, M.M.; Santos, R.H.S.; Freitas, G.B.; Martinez, H.E.P.; Garcia, S.L.R.; Finger, F.L. 2004. Growth and yield of coffee plants in agroforestry and monoculture systems in Minas Gerais, Brazil. Agroforestry Systems 63: 75-82.

Cannell, M.G.R. 1985. Physiology of the coffee crop. p. 108-134. In: Clifford, M.N.; Willson, K.C., eds. Coffee: botany, biochemistry and production of beans and beverage. Croom Helm, London, UK.

Da Matta, F.M. 2004. Ecophysiological constraints on the production of shaded and unshaded coffee: a review. Field Crops Research 86: 99-114.

Donald, P.F. 2004. Biodiversity impacts of some agricultural commodity production systems. Conservation Biology 18: 17-37.

Farfan, V.F.; Mestre, E.A. 2004. Response of coffee in an agroforestry system to fertilization. Cenicafé 55: 161-174. (in Spanish).

Jaramillo, C.; Martinez, H.E.P.; Santos, R.H.S. 2006. Characteristics of shade-grown coffee (Coffea arabica L.) in North of Latin America and Brazil: a comparative analysis. Coffee Science 1: 94-102. (in Portuguese, with abstract in English).

Jaramillo-Botero, C., Santos, R.H.S.; Martinez, H.E.P.; Cecon, P.R.; Fardin, M.P. 2009. Production and vegetative development of coffee trees grown under solar radiation and fertilization levels, during years of high and low yield. American-Eurasian Journal of Agricultural and Environmental Science 6: 143-151.

van Kanten, R.; Beer, J.; Schroth, G.; Vaast, P. 2004. Competitive interactions between Coffea arabica and fast-growing timber trees in Perez Zeledon, Costa Rica. Agroforesteria en las Americas 41/42: 5-15.

van Kanten, R.; Vaast, P. 2006. Transpiration of arabica coffee and associated shade tree species in sub-optimal, low-altitude conditions of Costa Rica. Agroforestry Systems, 67: 187-202.

Lin, B.B. 2007. Agroforestry management as an adaptive strategy against potential microclimate extremes in coffee agriculture. Agricultural and Forest Meteorology 144: 85-94.

Lin, B.B. 2009. Coffee (Café arabica var. Bourbon) fruit growth and development under varying shade levels in the Sonocusco region in Chiapas, Mexico. Journal of Sustainable Agriculture 33: 51-65.

Lin, B.B.; Richards, P.L. 2007. Soil random roughness and depression storage on coffee farms of varying shade levels. Agricultural Water Management 92: 194-204.

Morais, H.; Caramori, P.H.; Koguishi, M.S.; Gomes, J.C.; Ribeiro, A.M.A. 2009. Fructification and production. Ciência Rural 39: 400-406. (in Portuguese, with abstract in English).

Morais, H.; Caramori, P.H.; Ribeiro, A.M.A.; Gomes, J.C.; Koguishi, M.S. 2006. Microclimatic characterization and productivity of coffee plants grown under shade of pigeon pea in Southern Brazil. Pesquisa Agropecuária Brasileira 41: 763-770.

Morais, H.; Marur., C.J.; Caramori, P.H.; Ribeiro, A.M.A.; Gomes, J.C. 2003 Physiological characteristics and growth of coffee plants grown under shade of pigeonpea and unshaded. Pesquisa Agropecuária Brasileira 38: 1131-1137. (in Portuguese, with abstract in English).

Neves, Y.P.; Martinez, H.E.P.; Amaral, J.F.T.; Souza, R.B.; Domingos, D.R. 2006. Yield and accumulation of dry matter, N, P and K on Coffea arabica L. cultivars. Coffee Science 1: 156167. (in Spanish, with abstract in English). 
Neves, Y.P.; Martinez, H.E.P.; Souza, C.M.; Cecon, P. R. 2007. Soil moisture and soil fertility of coffee in agroforestry systems. Revista Árvore 31: 575-588. (in Portuguese, with abstract in English).

Peeters, L.Y.K.; Soto-Pinto, L.; Perales, H.; Montoya, G.; Ishiki, M. 2003. Coffee production, timber and firewood in traditional and Inga-shaded plantations in Southern Mexico. Agriculture, Ecosystems and Environment 95: 481-493.

Prezotti, L.C.; Rocha, A.C. 2004. Coffee nutrition as a function of plant density and NPK fertilization. Bragantia 63: 239-251. (in Portuguese, with abstract in English).

Rodríguez, L.; Valdés, R.; Verdecia, J.; Arias, L.; Medina, R.; Velasco, E. 2001. Growth, relative water content, transpiration and photosynthetic pigment content in coffee trees (Coffea arabica L.) growing at different sunlight regimes. Cultivos Tropicales 22: 37-41.

Romero-Alvarado, Y.; Soto-Pinto, L.; Garcia-Barrios, L.; BarreraGaytán, F. 2002. Coffee yields and soil nutrients under the shades of Inga sp. vs multiple species in Chiapas, México. Agroforestry Systems 54: 215-224.
Schaller, M.; Schroth, G.; Beer, J.; Jiménez, F. 2003. Species and site characteristics that permit the association of fast-growing trees with crops: the case of Eucalyptus deglupta as coffee shade in Costa Rica. Forest Ecology and Management 75: 205-215.

Silva, E.A.; Da Matta, F.M.; Ducatti, C.; Regazzi, A.J.; Barros, R.S. 2004. Seasonal changes in vegetative growth and photosynthesis of Arabica coffee trees. Field Crops Research 89: 349-357.

Tavares-Júnior, J.E.; Favarin, J.L.; Dourado-Neto, D.; Maia, A.H.N.; Fazuoli, L.C.; Bernardes, M.S. 2002. Comparative analysis among methods of estimating coffee-tree leaf area. Bragantia 61: 199-203. (in Portuguese, with abstract in English).

Received June 29, 2009

Accepted July 07, 2010 